\title{
THE METABOLISM OF NITROGEN, PHOSPHORUS AND THE PURIN SUBSTANCES IN THE NEW-BORN; WITH SPECIAL REFERENCE TO THE CAUSATION OF THE URIC ACID INFARCTS OF THE KIDNEY *
}

\author{
OSCAR M. SCHLOSS, M.D., AND JAMES L. CRAWFORD, M.D. \\ NEW YORK \\ TROY, TEXAS
}

\section{INTRODUCTION}

During the first few days in the life of an infant a number of phenomena may occur which border closely on the pathologic, among which is the frequent, if not constant, deposit of uric acid or its salts in the kidney tubules. Numerous investigations have been directed toward the solution of the etiology of this condition, in spite of which a number of the factors concerned are still obscure. Our own investigation was undertaken in the effort to determine the uric acid output, the factors on which it depends, and certain related problems of metabolism in the new-born infant.

It is a common observation that the urine of the new-born is often turbid and frequently leaves a deposit of uric acid or urates on the napkin; and in a large percentage of the infants who die during the first few days of life, a deposit of uric acid or urates ${ }^{1}$ is found in the medullary portion of the kidney-the so-called uric acid infarcts. It has been observed that these deposits are rarely present in dead-born infants; that they are found with greatest frequency in infants dying between the second and eighth days of life, and that their occurrence is infrequent after the twentieth day.

In 282 autopsies on living-born infants collected by Hodann, ${ }^{2}$ infarcts were present in 117 cases ( 42 per cent.). Hecker ${ }^{3}$ noted their presence in 40 per cent. of infants who had lived from a few hours to two months. Salomenson's ${ }^{4}$ statistics show their presence in 39 per cent. of 462 livingborn infants.

* From the Laboratory of Biological Chemistry of Columbia University at the College of Physicians and Surgeons, New York, and the New York Nursery and Child's Hospital.

1. Reusing and Ebstein considered that the uric acid was deposited as such. Parrot and Salomenson believed that it occurred as sodium urate, while Flensberg and Virchow thought that the infaret salt was ammonium urate. The analysis of Sjöqvist indicates that the uric acid is deposited as acid ammonium urate, or perhaps a mixture of this salt and neutral ammonium urate.

2. Quoted by Czerny and Keller: Des Kindes Ernährung, Ernährungsstörungen, etc., 1906, p. 167 , etc.

3. Hecker: Virchow's Arch. f. path. Anat., 1857, xi, 217.

4. Salomenson: Quoted by Flensberg. 
It was shown by Martin and Ruge, ${ }^{5}$ Parrot and Robin, ${ }^{6}$ Virchow, Hofmeier, ${ }^{8}$ Ebstein, ${ }^{9}$ Flensberg ${ }^{10}$ and others that the infarct elementshyaline or granular cylinders or spheres incrusted with uric acid or urates-are frequently present in the urine of the new-born and are identical with those found in the kidney. In sixty-three observations on infants from birth to 8 days of age by Hofmeier, these elements were found in 62 per cent. ${ }^{11}$ In the reports collected by Flensberg, their presence was noted for the urines of 101 (58 per cent.) of $1 \% 3$ infants from birth to the sixth day of life. They were present in nearly 90 per cent. of the cases in which the urine was examined during the last half of the first day and during the second day of life. The results were positive in all of the twenty infants examined by Flensberg. These results led Flensberg to believe that the causation of such infarcts is a physiologic processs and occurs to some degree in all new-born infants.

A great number of hypotheses have been advanced to explain the causation of the infarcts. Schlossberger ${ }^{12}$ considered that intestinal disturbances gave rise to an increased excretion of uric acid, and that a sedimentation of the urine was induced by a contraction of the urinary tubules, due to a low body temperature. Virchow attributed their occurrence to the revolution of metabolism which occurred at birth. Miller ${ }^{13}$ sought their explanation in a low temperature, insufficient respiration and oxidation, and renal congestion due to increased work thrown on the heart. Vierordt ${ }^{14}$ considered that the feeble powers of oxidation, and the concentration of the urine due to the small fluid intake, were the important factors. Coming to the more specific explanations we have that of Ebstein" who thought that there was a primary deposit of uric acid which caused a necrosis of the kidney parenchyma, and thus gave rise to the infarct stroma. The uric acid excretion in the new-born was determined by Reusing ${ }^{15}$ who found that it was very high. He considered that this high uric acid output, and the high acidity of the urine were the predisposing factors; the exciting cause was the great concentration of the urine due to the deficient fluid intake. Sjöqvist ${ }^{16}$ deter-

5. Martin and Ruge: Ztschr. f. Geburtsh. u. Frauenkr., 1876, i, 273.

6. Parrot and Robin: Arch. gên. de méd., 1876, i, 129, 309.

7. Virchow: Gesammelte Abhandlungen zur wissensch. Med., 1856, p. 833.

8. Hofmeier: Virchows Arch. f. path. Anat., 1882, lxxxix, 493.

9. Ebstein: Die Natur und Behandlung der Harnsteine, Wiesbaden, 1884.

10. Flensberg: Nörd. Med. Ark., 1894, No. 9, N. S.; Centralbl. f. inn. Med., 1894, xv, 965.

11. Hofmeier found the infarcts in a much larger percentage of infants whose mothers had been chloroformed during labor.

12. Schlossberger: Quoted by Czerny and Keller, p. 160.

13. Miller: Jahrb. f. Kinderh., 1886, xxv, 187.

14. Vierordt: Gerhardt's Handbuch der Kinderkrankheiten, 1877, i, 147.

15. Reusing: Ztschr. f. Geburtsh. u. Gynäk., 1895, xxxiii, 36.

16. Sjöqvist: Nörd. Med. Ark., 1894, No. 10, N. S.; Maly's Jahresb., 1894, xxiii, 245. 
mined the uric acid in catheterized specimens of urine obtained by Flensberg, and found that there was a great increase during the infarct period-the last half of the first day and the second day of life. Flensberg $^{10}$ considered that the exciting cause of the infarcts was the excretion of an albuminous material into the tubuli contorti during fetal life and shortly after birth. The casts which formed the groundwork for the infarcts were thus developed, and, coming in contact with the concentrated urine, received a deposit of uric acid.

The problem of the etiology of this condition presents, therefore, two important phases for solution. First, the cause for the high uric acid output shown by Reusing and Sjoqvist, and next, the cause for the deposit of uric acid in the kidney tubules. It was toward the solution of the former that this investigation was especially directed.

\section{EXPERIMENTAL}

Technic.-Observations were conducted on nine full term, male infants who were nursed by their own mothers. Labor was normal in all cases. The mothers received only small amounts of chloroform; never enough to induce narcosis, and rarely more than 30 c.c. All of the infants were apparently normal at birth and remained so during the period of observation. Two of the infants showed a very mild degree of jaundice (Protocols IV and VI).

The urine was collected by means of a drawn out test-tube which was fastened over the well lubricated penis, and connected by means of glass and rubber tubing to a bottle attached to the side of the crib. Powdered thymol was used as a preservative. The glass tube was attached by means of wool knitting floss and adhesive plaster. The floss strands were arranged so as to encircle the body and thighs; the adhesive plaster was used to attach the glass tube to the floss bands. The method has the advantage that the adhesive plaster does not touch the delicate skin of the infant, thus avoiding all irritation; that it can be used in circumstances where restraint is not permitted; and that the apparatus needs no readjustment at the time of maternal nursing. It has the great disadvantage that part of the urine may be lost unless the infant is closely watched, and unless the body is elevated or the glass tube fastened to the napkin and set slantingly so that there is a gradual incline from the penis to the collecting bottle. To obviate this difficulty the infants were kept on their sides and the tube included in the portion of the napkin which passed around the lower thigh. As a further precaution, a layer of absorbent cotton was wrapped around the upper end of the glass tube so that any leakage of urine could be easily detected. Occasionally, edema of the prepuce developed, but in most instances it was slight and was due to insufficient lubrication of the penis, or the tube was fastened so tightly around the base of the penis that it interfered with the circulation. The edema usually subsided promptly on correction of the underlying fault, 
but in two instances it was sufficiently severe to require removal of the apparatus before the conclusion of the experiment. The feces were collected by means of thin rubber napkins and were washed into a suitable receptacle with small quantities of distilled water.

The uric acid was determined by the method of Folin and Shaffer, ${ }^{17}$ the acidity by the method of Folin, ${ }^{18}$ the total nitrogen by the Kjeldahl process, and the purin content of the milk and feces by the method of Krüger and Schittenhelm. ${ }^{19}$ Phosphorus was determined gravimetrically as magnesium pyrophosphate after oxidation by the method of Xeumann. ${ }^{20}$ The method for the purin bases varied depending on the amount of urine available. Either Kenneway's modification of the Cammerer-Arnstein method, ${ }^{21}$ or the method of Krïger and Schmid ${ }^{22}$ was used. In the latter the precipitation was made from an acid solution as advised by Benedict and Saki. ${ }^{23}$ The specific gravity was determined with a small hrdrometer standardized against distilled water.

The determinations were made in duplicate whenever the amount of material permitted, and all procedures were carefully checked. Blank nitrogen determinations were made with each series and the results deducted from the actual determinations. The leukocytes were counted by means of the Thoma-Zeiss apparatus and the counts were made at the same time each day-directly before a nursing.

As a matter of convenience the periods were taken from 9 a. $\mathrm{m}$. to 9 a. $m$. The first day period varied, but extended from the time of birth to 9 a. $\mathrm{m}$. the next day, when this period approximated twenty-four hours, and when the amount of urine was sufficient for examination. Otherwise. the period was extended another twenty-four hours. The exact time in each case is shown in the protocols.

The urine of the first few days often contained a sediment which it was necessary to dissolve before proceeding with the chemical examination. This was done by diluting with hot distilled water and adding, when necessary, a few drops of a 1 per cent. solution of sodium hydroxid.

It has been shown by Budin, ${ }^{24}$ Rebemont, ${ }^{25}$ Shücking, ${ }^{26}$ Schiff,, ${ }^{27}$ Hofmeier ${ }^{28}$ and others that the total blood mass of the new-born infant may be influenced to a considerable degree by the time of ligation of the umbil-

17. Folin: Am. Jour. Physiol., 1905, xiii, 49.

18. Folin: Am. Jour. Physiol., 1905, xiii, 53.

19. Krüger and Schittenhelm: Abderhalden's Handbuch der Biochemie, 1910, iii, 893.

20. Sherman: Organic Chemical Analysis, 1905.

21. Kenneway: Jour. Physiol., 1909, xxxix, 296.

22. Kriger and Schmid: Ztschr. f. physiol Chem., 1905, xlv, 1.

23. Benedict and Saki: Jour. Biol. Chem., 1909, vii, 27.

24. Budin: Quoted by Rebemont (see note 25).

25. Rebemont: Arch. de Tocologie, 1879, vi, 572.

26. Shücking: Berl. klin., Wehnschr., 1877, xiv, 5.

27. Schiff: Jahrb. f. Kinderh., 1892, xxxiv, 159; Ibid, 1893, xxxv, 21.

28. Hofmeier: Ztschr. f. Geburtsh. u. Gynäk., 1897, iv, 114. 
ical cord. By various means, it has been determined that when the infant is left attached to the placenta some time after birth, it receives from 38 to 100 grams more blood than when the cord is ligated immediately after birth. According to Hofmeier the infant's blood mass may be thus increased by about one-third. Since it is only rational to suppose that there would be differences in the physiology of the new-born infant, dependent on the time of ligation of the umbilical cord, some of which have been shown by Hofmeier, ${ }^{28}$ Schiff ${ }^{27}$ and Reusing, ${ }^{15}$ our cases have been divided into two series. In one series of four cases the umbilical cord was ligated immediately after birth, in the other five cases the infants were left in contact with the placenta for from two to five minutes after the pulsation of the cord had ceased.

Quantity and Physical Characteristics of the Urine.-The quantity of urine excreted, its relation to the fluid intake, and the specific gravity of the urine have been determined by a number of observers (Parrot and Robin, ${ }^{6}$ Martin and Ruge, ${ }^{5}$ Schiff, ${ }^{27}$ Reusing, ${ }^{15}$ Hofmeier, ${ }^{28}$ Cruse ${ }^{29}$ and others), and from much larger series of cases than we have had at our disposal. For this reason it is unnecessary to give detailed consideration to these characteristics. In conformity with the results of Hofmeier, Schiff and Reusing, the late ligation cases slowed a greater urine excretion during the first few days than did the early ligation cases.

In all of our cases the appearance of the urine was noted, and the sediment, when present, or, in its absence, a centrifugalized specimen was examined microscopically. Epithelial cells and granular and hyaline casts were present in all cases at some time during the first four days. In all cases the urate spheres or uric acid cylinders were found at one time or another during the first three days. If the presence of the infaret elements in the urine signifies the occurrence of infarction-which there is no reason to doubt-our results agree with those of Flensberg, and indicate that the deposit of uric acid in the kidney is a regular occurrence in the new-born infant.

Uric Acid.-Reusing ${ }^{15}$ determined the total uric acid elimination in the new-born by the method of Hopkins, and Sjöqvist, ${ }^{16}$ the percentages by the Ludwig-Salkowski method. The uric acid values obtained by Reusing, Sjöqvist and those from our cases are shown in Table 1.

The values of Reusing are practically constant, with the exception of the increased excretion on the third day. Reusing explained this increase on the basis of the increased amount of urine excreted on this day, which was thus able to dissolve larger amounts of uric acid. Our values are higher than those of Reusing during the first four days; for the fifth, sixth and seventh days the average excretion was greater in Reusing's cases. A further and more important difference arises from the fact that while the average excretion in Reusing's cases was almost constant, with

29. Cruse: Jahrb. f. Kinderh., 1877, xi, 393. 
the exception of the third day, ours showed a rapid increase during the second and third days and then a diminution..$^{30}$ The relatively high excretion of uric acid in infancy is readily seen when the values in Table 1 are compared with the adult values of 300 to $600 \mathrm{mg}$. of endogenous uric acid per day (Burian and Schur).

TABLE 1.-The Uric Acid Elimination in the New-Born

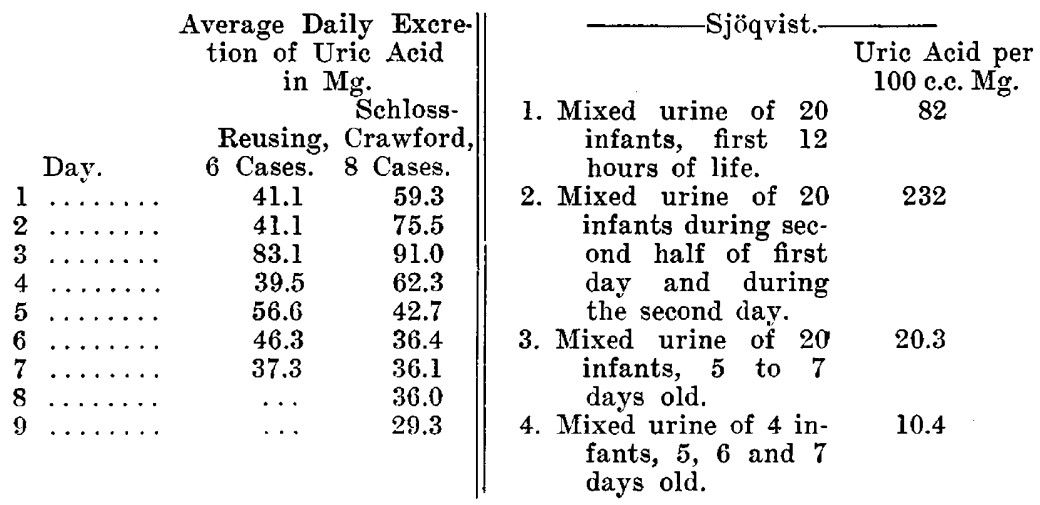

The percentage determinations of Sjöqvist cannot be accurately compared with those of Reusing or ourselves, owing to the difference in the periods. His results, however, show a close relationship between the uric acid elimination and the occurrence of the infarcts. The uric acid was comparatively low before the infarct period, rose to a high level during the infarct period, and then sank to its lowest value. This relationship is also shown by our results when they are arbitrarily divided into threeday periods (Table 2 ).

TABle 2.-The Uric-Acid Elimination During Three-Day Periods Period.

Average Excretion of Uric Acid, $\mathrm{Mg}$.

1. First, second and third days............. 75.2

2. Fourth, fifth and sixth days...................

3. Seventh, eighth and ninth days............. 33.8

Nieman ${ }^{31}$ has determined the uric acid output in a new-born infant and the results are approximately the same as those in our cases. Nieman found, however, only a trace of uric acid during the first day, while the maximum excretion of $99.0 \% \mathrm{mg}$. occurred on the fourth day. After the fourth day the uric acid excretions in this case, and in two others-one

30. In the individual cases the uric-acid excretion varied rather widely, but was usually lower on the first than on the second or third day. This, however, is not without exception (Protocols VII and VIII). These variations are due, in part, at least, to the fact that our first-day period often consisted of more than twenty-four hours. From the end of the first day the numbered days were exactly twenty-four hours each, but owing to the variations in the first day, the later days as numbered in the protocols and tables do not always indicate the exact time from birth.

31. Nieman: Jahrb. f. Kinderh., 1910, lxxi, 286. 
an infant of 6 days, the other of 8 days-were practically the same as those in our cases.

Orgler ${ }^{32}$ determined the uric acid elimination in two breast-fed infants aged 11 days. The average daily excretion was 41.3 and $43.3 \mathrm{mg}$., respectively, which values are somewhat greater than those obtained by us for the urine of the ninth day.

In our cases there were certain differences in the uric acid output in the two series-the early and late ligations. These are shown in Table 3.

TABLE 3.-Uric-Acid Excretion in The Immediate and Late Ligation Cases

\begin{tabular}{|c|c|c|c|c|}
\hline \multirow[b]{2}{*}{ Day. } & \multicolumn{4}{|c|}{ Average. - Per Kilo of Body Weight. } \\
\hline & $\begin{array}{c}\text { Immediate } \\
\text { Ligation } \\
\text { (4 Cases). }\end{array}$ & $\begin{array}{c}\text { Late } \\
\text { Ligation } \\
\text { (4 Cases). }\end{array}$ & $\begin{array}{c}\text { Immediate } \\
\text { Ligation } \\
\text { (4 Cases). }\end{array}$ & $\begin{array}{l}\text { Late } \\
\text { Ligation } \\
\text { (4 Cases). }\end{array}$ \\
\hline$\ldots \ldots \ldots \ldots$ & 60.7 & 57.8 & 16.7 & 16.4 \\
\hline 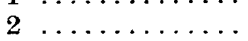 & 57.5 & 89.0 & 15.8 & 26.7 \\
\hline$\ldots \ldots \ldots \ldots$ & 82.3 & 102.6 & 24.0 & 30.9 \\
\hline$\ldots \ldots \ldots \ldots$ & 64.0 & 60.0 & 18.3 & 18.2 \\
\hline$\ldots \ldots \ldots \ldots$ & 44.9 & 40.3 & 12.7 & 12.1 \\
\hline$\ldots \ldots \ldots \ldots$ & 36.8 & 36.6 & 10. & 10.5 \\
\hline$\ldots \ldots \ldots \ldots$ & 35.9 & 36.3 & 9.6 & 10.6 \\
\hline$\ldots \ldots \ldots \ldots$ & 36.7 & 35.3 & 9.7 & 10. \\
\hline$\ldots \ldots \ldots \ldots$ & 29.2 & 29.4 & 8.4 & 9.6 \\
\hline
\end{tabular}

The most important differences occur in the values for the second and third days. For these days the average uric acid excretion and the excretion per kilo of body weight was much greater in the late ligation cases. Throughout the period of observation, with the exception of the first, fourth and fifth days, the uric acid output per kilo was greater in the late ligation cases; but the differences after the third day are slight and are not decided enough to be of significance for such a small series of cases. The average excretion after the third day is greater for some days in the immediate ligations, for others in the late ligations, but the differences are too slight to offer conclusive evidence in favor of either series.

Reusing ${ }^{15}$ observed that uric acid infarcts were less common in artificially fed infants than in those which had been nursed by their own mothers. This difference has been attributed to the greater urine excretion (from greater fluid ingestion) in the artificially fed. There is, however, another important difference. During the first two or three days of life the breast-fed infant receives colostrum which differs considerably from mature milk in both its physical and chemical characteristics. Milk is generally considered as practically purin free, and the uric acid excretion in infancy is in consequence entirely endogenous. But this applies only to the mature milk. When one considers the cellular content of colostrum as shown by microscopic examination, and the acute congestion of the breasts during the establishment of the milk secretion, it is only rational to suppose that colostrum contains an appreciable amount of

32. Orgler: Jahrb. f. Kinderh., 1908, lxvii, 383. 
purin nitrogen. The results of our determinations in this connection are shown in the accompanying Table 4.

Table 4.-The Pgrin Content of Colostrum and the Mitu Secretiox of the First Eleven Days

Colostrum *

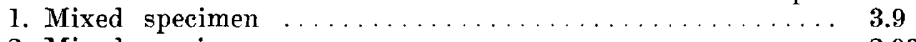

2. Mixed specimen $\ldots \ldots \ldots \ldots \ldots \ldots \ldots \ldots \ldots \ldots \ldots$

3. Mixed specimen $\ldots \ldots \ldots \ldots \ldots \ldots \ldots \ldots \ldots \ldots \ldots \ldots$

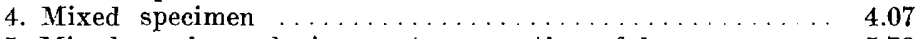

5. Mixed specimen during acute congestion of breasts..... 5.73

6. Mixed specimen during acute congestion of breasts..... 5.9

7. Mixed specimen Case (protocol) IX, for first three days.. 4.7

Milk-Mixed Specimens-

1. First and second days of true lactation............ 2.64

2. First and second days of true lactation............ 2.49

3. Third and fourth days of true lactation............ 1.69

4. Sixth and seventh days of true lactation.......... 0.57

5. Seventh and eighth days of true lactation.......... 0.92

6. Tenth and eleventh days of true lactation.......... 0.9

7. Case (protocol) IX, fourth, fifth and sixth days........ 1.8

8. Case (protocol) IX, seventh, eighth and ninth days..... 0.8

* We wish to acknowledge our indebtedness to Dr. Wilbur Ward, Resident Physician at Sloan Maternity Hospital, for his kindness in obtaining Specimens 3 and 5.

These results show that colostrum contains an appreciable amount of purin nitrogen, which rises to its highest value during the acute congestion of the breasts, and then gradually falls. To determine what influence the purin nitrogen of colostrum might exert on the purin excretion in the new-born, we have determined the intake of colostrum in five cases by weighing the infant before and after each nursing. In four cases the purin nitrogen was calculated from the figures shown in Table 4 . In Case 9 the purin nitrogen was determined in a composite specimen of milk obtained by pumping the mother's breasts before and after each nursing. In the first four cases the purin nitrogen was determined in the feces for the period, but in Case 9 the feces were not examined for purin nitrogen owing to their use for other purposes. The usual calculations for absorption give the results shown in Table 5 .

\begin{tabular}{|c|c|c|c|}
\hline se $4 \ldots$ & $\begin{array}{c}\text { Purin Nitrogen } \\
\text { Ingested, Mg. } \\
27.6\end{array}$ & $\begin{array}{c}\text { Purin Nitrogen } \\
\text { in Feces, Mg. } \\
11.6\end{array}$ & $\begin{array}{c}\text { Purin Nitrogen } \\
\text { Absorbed,Mg. } \\
\text { J6. }\end{array}$ \\
\hline se 5 & 13.4 & 12.2 & 1.2 \\
\hline e 6 & 18.3 & 15.3 & 3. \\
\hline & 23.1 & 18.3 & 4.8 \\
\hline
\end{tabular}

Judging from these figures only a small amount of purin nitrogen is absorbed, and with the possible exception of Case 4, the quantity of uric acid from this source is negligible. A large proportion of the purin nitrogen in colostrum is probably bound in the nuclei of the colostrum corpuscles, epithelial cells and leukocytes. There is no proof that the new-born 
infant is able to digest and absorb purin in these forms. There is, however, a great fallacy in the calculations for absorption. The stools of this period consist in part of meconium, which is formed in intrauterine life, and which contains a comparatively large amount of purin nitrogen. It was shown by Weintraud ${ }^{33}$ and later by Schittenhelm ${ }^{34}$ that meconium contains uric acid, which is probably derived from swallowed amniotic fluid. Meconium also contains epithelial cells which would serve as an additional source of purin nitrogen. ${ }^{35}$ In our cases the first meconium stools were excluded and the feces collected after the appearance of yellowish or greenish particles, indicating a food residue. But this precaution does not eliminate the fallacy, for it is impossible to mark the exact time when the meconium stools cease and the food stools begin. Some meconium is frequently passed for from two to five days, depending on the amount of food taken.

We have no data to show that the "integral factor" of Burian and Schur-that one-half of the purin nitrogen ingested appears in the urine-applies to the new-born infant. ${ }^{36}$ Assuming that this is the case, our calculations would be as shown in Table 6 .

TABLE 6.-The Excretion of Exogenous Purin Nitrogen Calculated from the Purin Nitrogen Ingested by Means of the "Integrad Factor"

$\begin{array}{cc}\text { Purin Nitrogen Output } & \text { Calculated Exogenous } \\ \text { During Colostral } & \text { Purin Nitrogen } \\ \text { Period, Mg. } & \text { for the Period, Mg. } \\ 90 & 13.8 \\ 77 & 6.7 \\ 717 & 9.1 \\ 94.9 & 11.5 \\ & 5.9\end{array}$

The purin nitrogen ingested during the first three days can, therefore, explain but a small portion of the purin nitrogen excreted in the urine. The purin nitrogen excreted in the urine must be mainly, if not entirely, endogenous.

Purin Base Nitrogen.-The excretion of purin base nitrogen varied considerably in the individual cases but was usually most during the time of the greatest uric acid excretion. This is shown in Cases (Protocols) $1,3,4, \%$, and 8 . In Case (Protocol) 6, the amount of excreted purin base nitrogen was relatively small, while the uric acid elimination was greatest. and rose to its highest level when the uric acid was decreasing. It seems probable that the high purin base excretion and the high uric acid excretion of the former perior were of the same origin, but for some

33. Weintrand: Centralbl. f. inn. Med, 1895, xvi, 433.

34. Schittenhelm: Deutseh. Arch. f. klin. Med., 1904, lxxxi, 423.

35. It is also true that a considerable portion of the purin nitrogen in the feces of adults does not originate from the food (Schittenhelm).

36. In experiments on infants more than 5 days of age, Nieman (see Note 31 ) found that the portion of the ingested purin nitrogen which was excreted in the urine was practically the same as in adults. It does not necessarily follow, however, that these experiments apply to the new-born infant. 
unknown reason the excretion of the former was delayed. An indication of this delayed excretion is seen in Case (Protocol) 1 , in which the highest uric acid and purin base values were not coincident. The purin bases showed only a slight increase at the time the uric acid was highest, but rose to their greatest values on the following days-times when the uric acid was decreasing. In Case (Protocol) 2 the excreted purin base nitrogen was comparatively small in amount during the entire period of observation, with the exception of a slight increase on the fourth day. The relation of the excretion of the purin bases to the uric acid excretion is shown in the new-born infant observed by Nieman $;^{31}$ there was a great increase in the purin base excretion when the uric acid values were increasing.

The average purin base excretion in our cases is shown in Table $\%$.

\begin{tabular}{|c|c|c|c|c|}
\hline 'TABLE & 7.-AVERAGE ExCRETION & PURIN & NItRogen & $($ Erght Cases) * \\
\hline & & & $\begin{array}{l}\text { Average Excre- } \\
\text { tion in } \mathrm{Mg} \text {. for }\end{array}$ & $\begin{array}{l}\text { Average Excre- } \\
\text { tion in } \mathrm{Mg} \text {. for }\end{array}$ \\
\hline & & $\begin{array}{l}\text { Average Exere- } \\
\text { tion in } \mathrm{Mg} \text {. }\end{array}$ & $\begin{array}{l}\text { Immediate } \\
\text { Ligations }\end{array}$ & $\begin{array}{l}\text { Late Liga- } \\
\text { tions }\end{array}$ \\
\hline 7 & Day. & $\begin{array}{c}\text { All Cases. } \\
5.3\end{array}$ & $\begin{array}{c}\text { (4 Cases) } \\
52\end{array}$ & $\begin{array}{c}\text { (4 Cases) } \\
5.5\end{array}$ \\
\hline $\begin{array}{l}1 \\
2\end{array}$ & $\begin{array}{l}\cdots \ldots \ldots \ldots \ldots \ldots \\
\ldots \ldots \ldots \ldots \ldots\end{array}$ & $\begin{array}{l}9.0 \\
9.3\end{array}$ & 7.9 & $\begin{array}{r}5.3 \\
10.8\end{array}$ \\
\hline 3 & ( & 8.1 & 6.5 & 9.7 \\
\hline 4 & $\ldots \ldots \ldots \ldots$ & 6.9 & 6.9 & 7.0 \\
\hline 5 & $\ldots \ldots \ldots \ldots \ldots \ldots$ & 6.1 & 7.3 & 5.1 \\
\hline 6 & $\ldots \ldots \ldots \ldots \ldots$ & 5.6 & 4.0 & 7.2 \\
\hline 7 & $\ldots \ldots \ldots \ldots \ldots \ldots$ & 3.7 & 3.3 & 4.0 \\
\hline 8 & $\ldots \ldots \ldots \ldots \ldots$ & 3.5 & 3.5 & 3.4 \\
\hline
\end{tabular}

* It is possible that these average figures do not indicate the true average quantities of purin base nitrogen, since the same method of estimation was not used in all cases. The variation was necessitated by the different and at times small quantities of urine available for this examination. This applies especially to Cases 1 and 2, in which the purin base nitrogen was determined in small quan. ties of urine. The results of the daily determinations in Cases 3 and 4 and the determinations for three-day periods in Cases 6, 7 and 8, are comparable, since the same methods were employed, with the use of approximately the same amounts of material.

Leukocytosis.- Soon after birth there is a great increase in the number of leukocytes and later a pronounced decrease. This has been shown by Gundobin, ${ }^{37}$ Schiff, ${ }^{38}$ and others. The average leukocyte count in our cases is shown in Table 8.

These figures show the high leukocyte count, and later, the great decrease of the leukocytes, during the first three days of life. In most instances our data are based on a single daily estimation, and therefore do not show the rather frequent fluctuation of the leukocytes during the first days of life. We cannot lay much stress on the differences shown between the immediate and late ligation cases as indicating the usual

37. Gundobin: Jahrb. f. Kinderh., 1893, xxxv, 187.

38. Schiff: Ztschr. f. Heilk., Prague, 1890, xi, 17; Jahrb. f. Kinderh., 1892, xxxiv, 169. 
conditions, for our series of cases is too small. Moreover, a single count each day is not sufficient for this purpose, but counts should be made at frequent intervals. Our results are merely intended to show the leukocyte count in the cases used in this investigation.

\begin{tabular}{|c|c|c|c|c|}
\hline \multirow[t]{3}{*}{ TABLE } & \multirow[t]{3}{*}{ 8.-Average Lleukocyte } & $\begin{array}{l}\text { Count For } \\
\text { CASES) }\end{array}$ & THE FIRST EIGHT & DaYs (EIGHT \\
\hline & & -Leukocytes & per Cubic mm. of 1 & Blood.- \\
\hline & & $\begin{array}{l}\text { Average, } \\
\text { All Cases. }\end{array}$ & $\begin{array}{l}\text { Average, } \\
\text { Immediate Li- } \\
\text { gations } \\
\text { (4 Cases). }\end{array}$ & $\begin{array}{c}\text { Average, Late } \\
\text { Ligations } \\
\text { (4 Cases). }\end{array}$ \\
\hline I & $\ldots \ldots \ldots, \ldots$ & 29,000 & 28,600 & 29,400 \\
\hline 2 & & 16,800 & 17,900 & 15,700 \\
\hline 3 & $\ldots$. & 11,800 & 13,700 & 9,900 \\
\hline 4 & $\ldots$. & 10,300 & 10,800 & 9,800 \\
\hline 5 & $\ldots \ldots \ldots \ldots$ & 10,600 & 10,200 & 11,100 \\
\hline 6 & $\ldots \ldots \ldots \ldots \ldots$ & 11,700 & 11,100 & 12,300 \\
\hline 7 & $\ldots \ldots \ldots \ldots$ & 12,000 & 10,200 & 13,900 \\
\hline 8 & 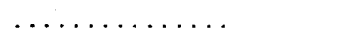 & 11,600 & 11,300 & 12,000 \\
\hline
\end{tabular}

Total Nitrogen.-The total nitrogen excretion in our cases agreed in general with the results of other observers, but as the quantity of nitrogen was not determined in the food of most of our cases, the total nitrogen values have no special significance. There was usually a rise in the excretion of total nitrogen during the third day, coincident with the greater uric acid excretion. But it was usually on this day that the secretion of the mother's milk began, and in consequence there was a greater nitrogen intake. After the third day the total nitrogen excretion was remarkably constant. In Case 9 (Protocol IX) the nitrogen balance was determined for three day periods. ${ }^{39}$ The data are given in Table 9.

In Case 4 (Protocol IV) the nitrogen balance was determined for the first three days, with the following results :40

Milligrams of nitrogen ingested, 2,870; milligrams of nitrogen in urine and feces, 1,418 ; balance, $+1,452=50.5$ per cent. of the nitrogen ingested.

During the first three days there was a nitrogen retention in both infants in spite of the loss of weight during this period. Both infants, however, began to gain weight on the first day of the following period. The three infants observed by Langstein and Nieman ${ }^{41}$ showed a nitrogen

39. The periods in this case were exactly 72 hours each. The food nitrogen was determined from a composite specimen of milk obtained by pumping the breasts before and after each nursing. There was very little colostrum in the breasts until the end of the second day. There were two feedings during the first day; subsequently the infant was nursed at three-hour intervals. The milk secretion began on the evening of the third day.

40. The period in this case was eighty-five hours. The determination of the food nitrogen and the technic of nursing was the same as in Case 9. There was a moderate amount of colostrum in the breasts. The milk secretion began about fifty-six hours post-partum, so that the infant's food during what is recorded as the third day (see Protocol IV), consisted, in part, of the first milk secretion.

41. Langstein and Nieman: Jahrb. f. Kinderh., 1910, lxxi, 604. 
loss during the first three days. These infants, however, were not nursed by their own mothers but were fed on milk which had been pumped from

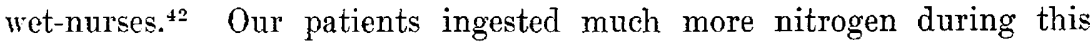
period, since they received colostrum, which is much richer in nitrogen than mature milk. ${ }^{43}$

Tabie 9.-Nitrogen Balance in Case 9 During the First Nine Days of

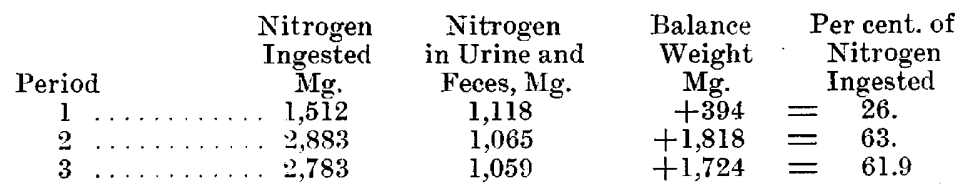

During the second and third periods-from the fourth to the ninth days inclusive-there was a greater retention of nitrogen by Case 9 than by the cases of Langstein and Nieman. In one of their cases there was a nitrogen loss for the fourth and fifth days; in a second there was a negative balance for the sixth, seventh and eighth days. Michel ${ }^{44}$ determined the nitrogen balance in one infant of four days, two of five days and one of seven days of age. The retention of the ingested nitrogen was i3 per cent., 75.7 per cent., $7 \% .2$ per cent., and 80 per cent., respectively. This higher nitrogen retention in Michel's cases was mainly due to the greater intake of nitrogen than in our case.

TABLE 10.-Comparison of the Average Excretion of Total Nitrogen to Total Purin Nitrogen

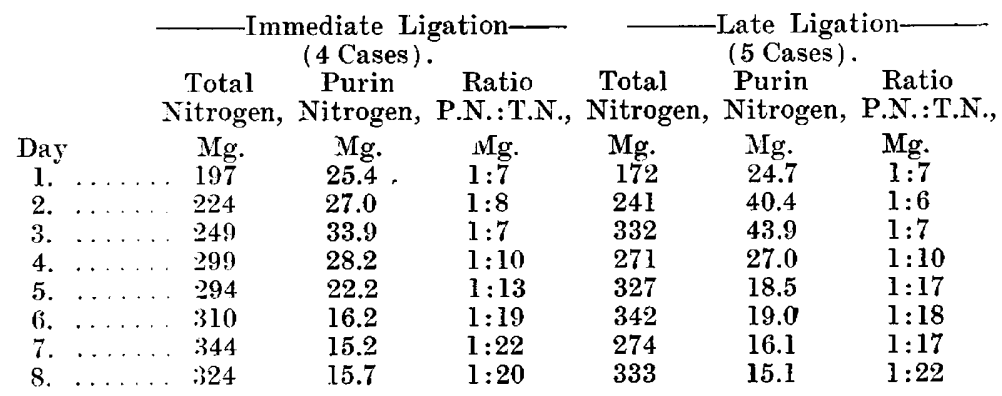

Phosphorus.--There have been only a few observations on the phosphorus excretion in the new-born, and these have given divergent results. Hecker ${ }^{45}$ in an infant of 3 months, and Harley ${ }^{46}$ in one of 6 months, found only traces of phosphorus. Martin and Ruge ${ }^{5}$ and Parrot and

42. This insured a more accurate control of the quantity and composition of the food.

43. Langstein and Nieman point out the fact that their patients received a food poorer in nitrogen than they would if they had been nursed by their own mothers and had received colostrum, instead of a more mature milk.

44. Michel: Quoted by Keller, Arch. f. Kinderh., 1900, xxiv, I; Czerny and Keller, 289 and 294.

45. Hecker: Virchow's Arch. f. path. Anat., 1857, xi, 217.

46. Harley: Quoted by Cruse (see note 29). 
Robin ${ }^{6}$ comment on the small phosphorus content of the urine of newborn infants. Cruse ${ }^{29}$ states that phosphorus may be present only in traces in the urine of the new-born, or may be entirely absent. In his observations on the excretion of phosphates (uranium acetate titration) Cruse found from 0.008 to 0.039 per cent. in the urine of infants of 5 to 10 days of age, 0.010 to 0.058 per cent. in the urine of infants of 10 to 30 days, and 0.015 to 0.032 per cent. in the urine of infants 30 to 60 days of age. In one of the patients 5 days of age studied by Michel, ${ }^{44}$ the average daily excretion of phosphorus was $22 \mathrm{mg}$. of $\mathrm{P}_{2} \mathrm{O}_{5}$ during a three-day period; a second infant 5 days of age excreted an average of $25 \mathrm{mg}$. of $\mathrm{P}_{2} \mathrm{O}_{5}$ a day during a four-day period. An infant of 7 days excreted a daily average of $34 \mathrm{mg}$. of $\mathrm{P}_{2} \mathrm{O}_{5}$ during a six-day period.

Moll ${ }^{47}$ has recently emphasized the clinical importance of an estimation of the urinary phosphates. He states that the urine of a normal, thriving, breast-fed infant contains from 10 to $20 \mathrm{mg}$. of $\mathrm{P}_{2} \mathrm{O}_{5}$ a day, which type of urine he regards as being practically phosphorus-free, and 10 c.c. of which requires only a few drops of uranium acetate solution for the complete precipitation of the contained $\mathrm{P}_{2} \mathrm{O}_{5}$. It was observed that hunger had no effect on the phosphate elimination, but that there was a greatly increased elimination during "alimentary intoxication" (Finkelstein).

It was noted in our earlier cases in which the phosphorus was not determined (Protocols I, II, III and IV), that during the first few days the addition of the uranium acetate reagent of Folin and Shaffer produced a well-defined precipitate of uranium phosphate. During the later days the addition of this reagent produced, at most, a faint cloud and never a distinct precipitate. The total phosphorus was determined in four cases during three-day periods. The results are given in Table 11.

TabLe 11.-The Excretron of Total Phosphorus in the Urine of Cases 6, 7, 8, and 9, Durixg Three-Day Periods

\begin{tabular}{|c|c|c|c|c|c|}
\hline \multicolumn{6}{|c|}{$\mathrm{P}_{2} \mathrm{O}_{5}$ in $\mathrm{Mg}$. } \\
\hline Case & 6 & 7 & 8 & 9 & Average \\
\hline Period 1. & 46 & 44 & 63.4 & 60.7 & 53.5 \\
\hline Period 2. & Trace* & Trace* & Trace* & 25.6 & 6.4 \\
\hline Period 3. & Trace* & 4.2 & 11.8 & 27.2 & 10.8 \\
\hline
\end{tabular}

*Gave a distinct precipitate of ammonium phospho-molybdate but the magnesium pyrophosphate precipitate was too small to weigh with accuracy. The phosphorus determinations were always made from as large a quantity of urine as possible; usually from one-fourth to one-half of the total urine for the period.

In Case 6 a daily determination was made after the third day. In Case $\%$ the phosphorus was determined in a composite specimen for the first three days, and for the seventh, eighth and ninth days, while a daily determination was made during the fourth, fifth and sixth days. In Cases 8 and 9 the phosphorus was determined in composite specimens for three-day periods. In Case 5 the urine of the second day was incomplete

47. Moll: Jahrb. f. Finderh., 1909, lxix, 128. 
and the phosphorus was determined in the composite specimen for the first and third, and the fourth and fifth days. The urinary phosphorus was as great during the fourth and fifth as during the first and third days. During the last day of observation the infant began to vomit and to suffer from a severe, watery diarrhea. This high phosphorus output on the fourth and fifth days is in marked contrast with the results in the other cases. This discrepancy may have been caused by an increased elimination of phosphorus, due to the gastro-intestinal disorder in harmony with Moll's view.

Langstein and $\mathrm{Nieman}^{41}$ have determined the phosphorus elimination in three new-born infants, but their results differ considerably from ours. Their cases did not show a greater phosphorus elimination during the first three days, but on the contrary, the excretion usually increased after this time.

In Case 9 (Protocol IX) the phosphorus balance was determined. The results are given in Table 12.

table 12.-The Phosphorus Balance in Case 9 During Three-Day Periods *

\begin{tabular}{|c|c|c|c|c|c|}
\hline Period & $\begin{array}{c}\mathrm{P}_{2} \mathrm{O}_{5} \\
\text { Ingested, } \\
\mathrm{Mg} .\end{array}$ & $\begin{array}{c}\mathrm{P}_{2} \mathrm{O}_{5} \text { in } \\
\text { Urine and } \\
\text { Feces, } \mathrm{Mg} \text {. }\end{array}$ & $\begin{array}{c}\text { Balance } \\
\text { Weight, } \\
\text { Mg. }\end{array}$ & & $\begin{array}{l}\text { Per cent. } \\
\text { of } \mathrm{P}_{2} \mathrm{O}_{5} \\
\text { Ingested }\end{array}$ \\
\hline 1. & 155.5 & 85.5 & +70 & $=$ & 45.0 \\
\hline 2. & 492.9 & 67.9 & +425 & $=$ & 86.2 \\
\hline 3. & 483. & 88.8 & +394.2 & $=$ & 81.6 \\
\hline
\end{tabular}

*The phosphorus content of the food was determined from a composite specimen of milk obtained by pumping the breasts before and after each nursing.

The percentage of phosphorus retained in this case closely corresponds with the results in Michel's $\mathrm{s}^{44}$ cases. Two infants of 5 days retained 87.3 and 77.3 per cent. of the phosphorus $\left(\mathrm{P}_{2} \mathrm{O}_{5}\right)$ ingested; an infant of 7 days retained 80.1 per cent. of the phosphorus intake.

Acidity.-The acidity of the urine was determined in Case 8 by the method of Folin. Both the absolute and the percentage acidity were greatest during the first three days. The highest percentage acidity was on the second day, the greatest absolute acidity on the third day.

\section{GENERAL CONSIDERATION OF THE URIC ACID EXCRETION AND THE CAUSATION OF THE URIC ACID INFARCTS}

The results of Reusing, Sjöqvist and ourselves show that there is a comparatively abundant output of uric acid from the new-born. Those of Sjöqvist and ourselves show that this excretion is greatest during the period in which post-mortem examination and the occurrence of infarct elements in the urine indicate that uric acid is deposited in the kidney tubules. There are two possible explanations for the high uric acid output in the new-born: (1) a normal uric acid formation and a diminished destruction, or (2) increased formation with normal or diminished destruction. 
Spiegelberg ${ }^{48}$ found that when $0.1 \mathrm{gm}$. of uric acid per kilo of body weight was injected into young puppies, 53 per cent. was excreted in the urine, while in adult animals only 5.6 per cent. of the injected uric acid could be thus recovered. He was able to produce deposits of uric acid in the kidneys of puppies by the injection of quantities which were without effect on the older animals. He further observed that, after the uric acid injections, the urine of the puppies became cloudy, while that of the older animals remained clear. These experiments indicated that the young animals were less able to destroy uric acid than were the adults, and suggested that a deficient uric acid destruction was perhaps the explanation of the high excretion in the new-born. This explanation was supported by the studies of Mendel and Mitchell, ${ }^{49}$ who observed that the uricolytic enzyme was the last to appear in the developing pig. Observations on the human organism, however, gave different results. Schittenhelm and Schmid ${ }^{50}$ were able to show an active uricolysis by the organs of the fetus and the new-born infant. These results are of particular interest in contrast with the results of Schittenhelm, ${ }^{51}$ and Künzel and Schittenhelm, ${ }^{52}$ who were unable to demonstrate the presence of a uricolytic enzyme in the organs of adults. Wells and Corper ${ }^{53}$ found no evidence of uricolytic activity in the organs of the fetus, the new born, or in those of adults. They therefore concluded that the human organism does not possess the ability to destroy uric acid. The results of Wiechowski $^{54}$ have a similar bearing, for he was able to recover in the urine a considerable portion of the uric acid injected into human beings (60 to 80 per cent.). Moreover, he was unable to demonstrate the presence of allantoin in the urine after the uric acid injections.

It seems, therefore, that the results of Spiegelberg on dogs are not applicable to the human organism. This variation is perhaps due to the fact that dogs normally have the power of destroying uric acid.

The second hypothesis-an increased uric acid formation-is favored by Reusing ${ }^{15}$ and by Flensberg. ${ }^{10}$ As shown by Gundobin, ${ }^{37}$ Schiff ${ }^{38}$ and others, soon after birth there is a rapid rise in the number of the leukocytes, which later shows a pronounced fall. The high uric acid formation was thus explained on the basis of Horbaczewski's theory.

The relationship of the leukocytes in the peripheral blood to the elimination of uric acid is a problem on which there is an enormous controversial literature, and which at the present time remains unsolved. There is little doubt that uric acid can arise from the nuclein of leukocytes, as

48. Spiegelberg: Arch. f. exper. Path. u. Pharmakol., 1898, xli, 428.

49. Mendel and Mitchell: Am. Jour. Physiol., 1907, xx, 97.

50. Schittenhelm and Schmid: Ztschr. f. exper. Path. u. Therap., 1907, iv, 424.

51. Schittenhelm: Ztschr. f. Physiol. Chem., 1909, lxiii, 248.

52. Künzel and Schittenhelm: Zentralbl. f. Physiol. u. Path. d. Stoffwech., 1908, iii, 721 .

53. Wells and Corper: Jour. Biol. Chem., 1909, vi, 321.

54. Wiechowski : Arch. f. exper. Path. u. Pharmakol., 1909, Ix, 185. 
well as from the nuclein of other tissues. The observations of Fränkel, ${ }^{55}$ Jakob, ${ }^{56} \mathrm{Jakob}$ and Krüger ${ }^{5 \tau}$ and Musser and Edsall ${ }^{58}$ in leukemia and of Kühnau ${ }^{58}$ and others in pneumonia, gives evidence of the origin of uric acid from leukocytes. We have no evidence to show, however, that the number of leukocytes in the peripheral blood is an accurate index of the total number of these cells, nor that a decrease in the leukocyte count means a leukocyte destruction. It has been demonstrated by Goldscheider and Jacob, ${ }^{60}$ Schulz, ${ }^{61}$ Bohland ${ }^{62}$ and others that a decreased number of leukocytes in the peripheral blood may only mean a changed distribution of these cells. These observers showed that when such a decrease was induced experimentally in animals, it was compensated by an accumulation of the leukocytes in the lung capillaries. In other words, these experiments indicate that fluctuations of the lenkocyte count do not necessarily signify changes in the total number of these cells, but may merely indicate altered proportions in the peripheral circulation and the internal organs.

The apparent relationship of the leukocyte count to the uric acid excretion is shown by the tabulated data for our cases. There was usually an inverse ratio between the leukocyte count and the uric acid elimination during the first four days. There was a great decrease in the leukocyte value during the period when the uric acid figures were largest, which coincides with the time when the uric acid infarcts occur. The excretion of phosphorus followed a similar course; it was high during the first three days and then fell sharply to quantities which were often too small to estimate. It is well known that nuclear material is rich in phosphorus as well as in the precursors of uric acid, and this parallelism in the excretion of uric acid and phosphorus strongly suggests that their joint origin is from cell nuclei. It therefore seems correct to attribute the augmented uric acid excretion to an increased formation of that substance.

A more difficult problem arises when we attempt to determine whether this uric acid originates from leukocytolysis or finds its origin in other tissues. The high uric acid excretion occurs at a period when the blood is undergoing rapid morphologic changes. During fetal life and shortly after birth many of the red cells contain nuclei which disappear during the first few days of life. Shortly after birth the leukocytic formula shows a predominance of the polynuclear neutrophilic cells, but within

55. Fränkel: Deutsch. med. Wchnschr., 1895, xxi, 639.

56. Jakob: Arch. f. Physiol. u. Anat. (Dubois-Reymond), Physiol. Abth., 1894, 378.

57. Jakob and Krüger: Deutsch. med. Wehnschr., I894, xx, 64l.

58. Musser and Edsall: Univ. Penn. Med. Bull., 1905, xviii, 174.

59. Kühnau: Ztschr. f. klin. Med., 1897, xxxii, 482 ; Deutsch. Arch. f. klin. Med., 1897, lviii, 339 .

60. Goldscheider and Jacob: Ztschr. f. klin. Med., 1894, xeviii, 373.

61. Schultz: Deutsch. Arch. f. klin. Med., 1893, li, 234.

62. Bohland: Centralbl. f. inn. Med., 1899, xx, 361. 
a few days the proportion changes and the typical infantile blood picture - a predominance of lymphocytes-is apparent $\left(\right.$ Carstanjen $\left.^{63}\right)$. There is at first an increase in the number of leukocytes in the peripheral blood, and later a pronounced decrease. It has been mentioned that when the new-born infant is left attached to the placenta some time after birth it receives a much larger amount of blood than when the umbilical cord is ligated immediately after birth. If the uric acid arises from the morphologic elements of the blood, it is to be experted that the excretion would be greater in the cases in which the umbilical cord was tied late. ${ }^{64}$ That

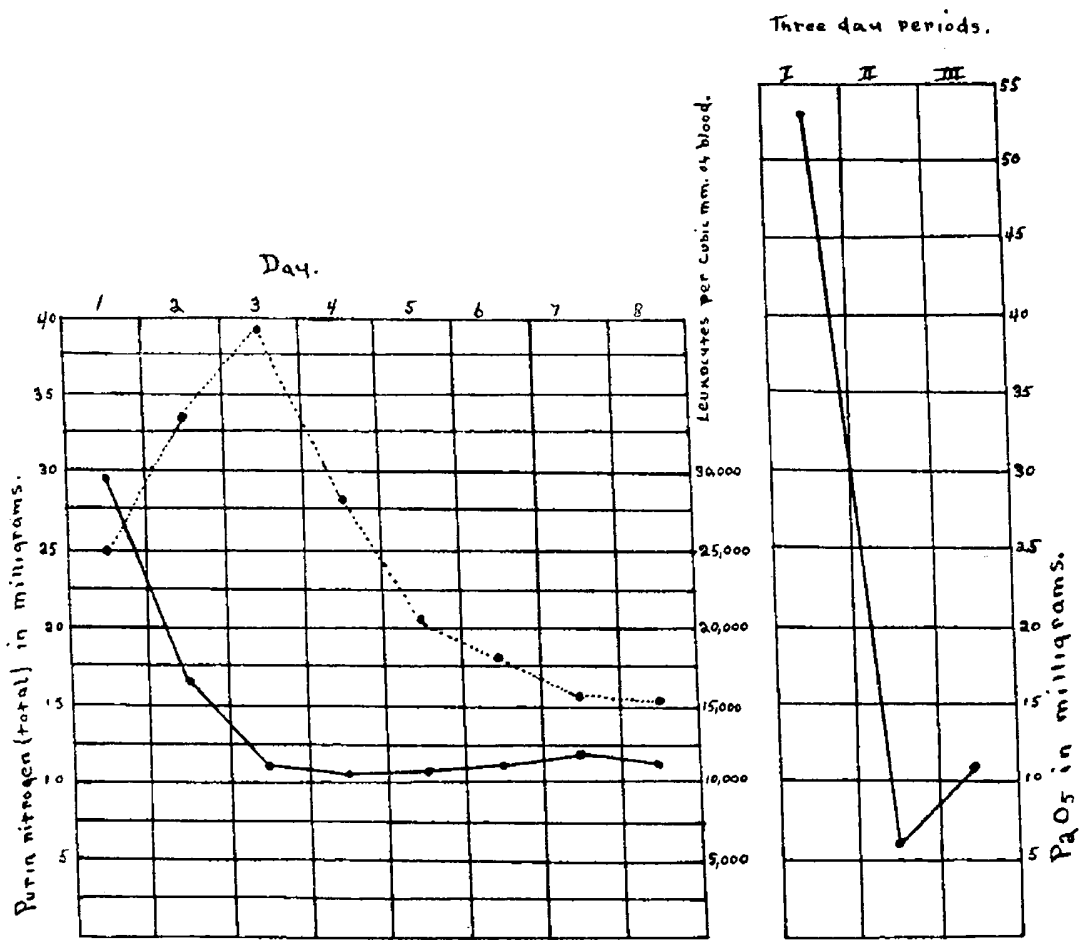

Curve 1.-Comparison of the leukocytosis with the excretion of $\mathrm{P}_{2} \mathrm{O}_{5}$ and total purin nitrogen. Leukocytes, continuous line; total purin nitrogen, dotted line. The data for the purin nitrogen and leukocytes were obtained from all of the cases.

63. Carstanjen: Jahrb. f. Kinderh., 1900, liii, 215.

64. Reusing has suggested that the uric acid output should be greater in late ligation cases if the increased excretion of that substance in the new born originated from leukocytolysis; but he apparently made no observations bearing on this problem. The work of Hofmeier and Silvermann indicates that there is a destruction of the blood elements in icterus neonatorum. On the basis of this observation, Reusing has suggested that if the uric acid originates from a destruction of blood cells, there should be a greater excretion of uric acid by jaundiced infants. The two cases observed by Reusing give no conclusive evidence on this point. Two of our cases (Protocols IV and VII) developed a mild grade of icterus neonatorum. The degree of jaundice was very slight, however, and was evidenced only by a faint yellow color of the conjunctiva. In neither case was the excretion of uric acid greater than in the infants without jaundice. 
this is the case is shown by the results from our cases. During the second and third days the average uric acid excretion, and the excretion in relation to the body weight, were greater in the late ligation cases. These observations would seem to indicate that the blood elements are in some way concerned with the increased uric acid formation in the new born. The pronounced decrease in the leukocyte count, and the disappearance of a great number of polynuclear cells from the peripheral blood, suggests that the uric acid arises from a leukocyte destruction. Although this evidence is suggestive, there is no proof that these changes signify a leukocyte destruction, and it is impossible to determine whether the uric acid arises wholly, or in part, from an increased number or an increased destruction of leukocytes, or from the extruded nuclei of the red cells. Perhaps it originates in some phase of metabolism concerned with the production of the formed elements of the blood.

The exciting cause for the deposition of uric acid in the kidney tubules is not entirely clear. We found that the acidity of the urine was greatest during the first three days, which is coincident with the formation of the infarcts. This high acidity of the urine may be a factor in causing the deposition of uric acid, for uric acid is readily thrown out of solution by increased acidity of the urine.

Any acceptable hypothesis must explain not only the deposit of the uric acid in the kidney but also the formation of the infarct elements and stroma. The uric acid is not deposited directly in the kidney tubules but is found in the characteristic cylinders and spheres. There are certain objections to Ebstein's hypothesis-the primary deposit of uric acid and a secondary formation of the infarct stroma through cell necrosis. Spiegelberg has shown that the urine of the new-born infant has great solvent powers for uric acid, and that urine which was turbid with urates was still able to dissolve considerable quantities. It is also well known that the urine of adults may contain very large amounts of uric acid; yet uric acid infarcts never occur in adult life.

The explanation of Flensberg was based on careful histologic examination of the kidney of the fetus and the new-born infant. He showed the presence of the cylinders in the kidney tubules before the occurrence of the infarcts. It remains to be determined whether the contact of these cylinders with the concentrated and highly acid urine is sufficient to excite a deposit of uric acid on their surface, or whether the deposition of the uric acid depends on some special physical or chemical characteristic of the urine.

\section{SUMMARY AND CONCLUSIONS}

1. Uric acid infarct elements were present in the urine of each of nine new-born infants. 
Immediate liqation of cord.
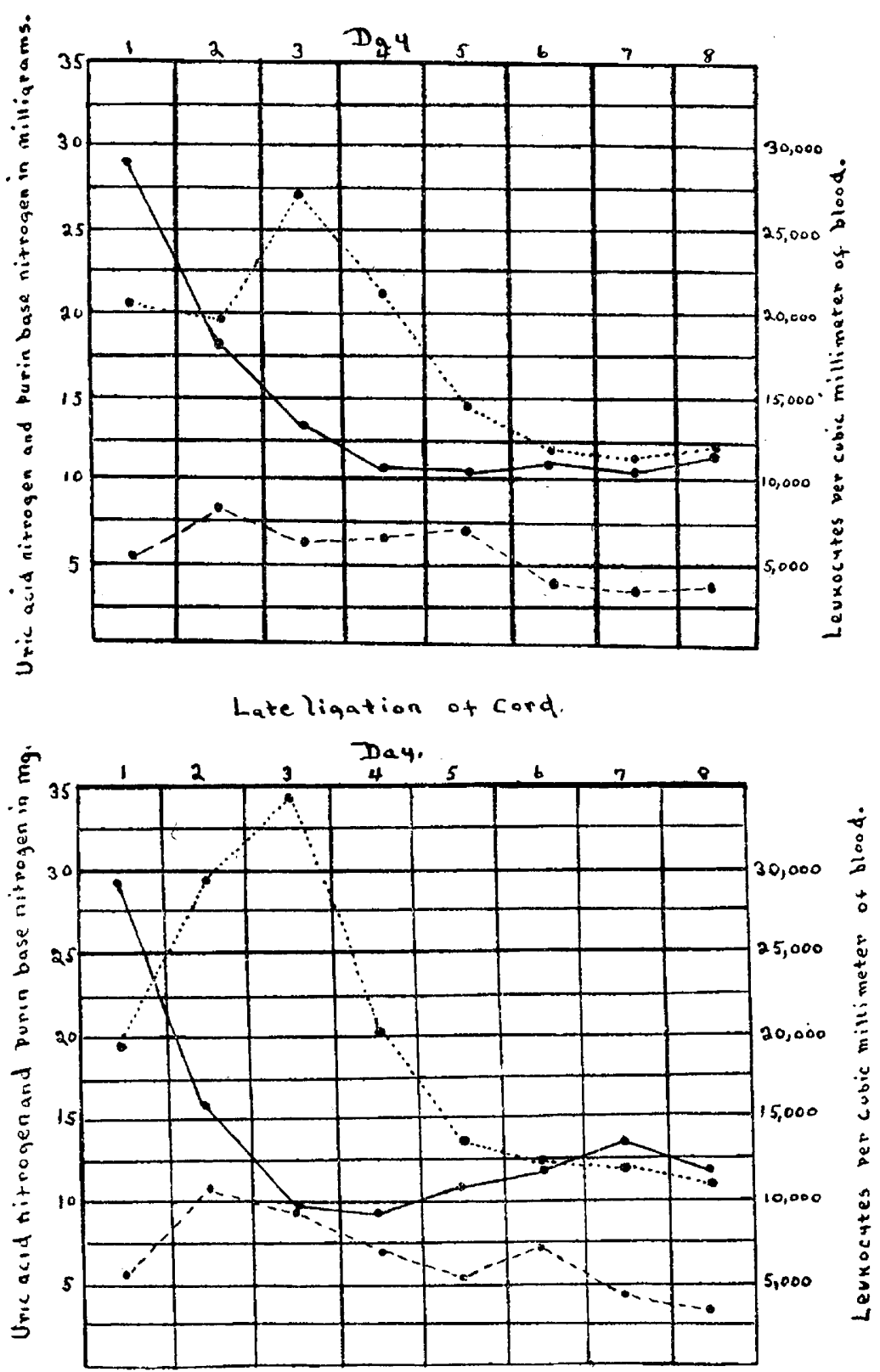

Curve 2.-Relation of the number of leukocytes (continuous line) to the elimination of uric acid nitrogen (dotted line) and purin base nitrogen (broken line). 
2. (a) The uric acid output in new-born infants is both absolutely and relatively high. It is greatest during the first three days and then decreases.

(b). In cases in which the umbilical cord was ligated late, the output of uric acid was greater during the second and third days than in cases in which the cord was ligated immediately after birth.

(c). The quantity of the purin substances in the colostrum ingested is too small to explain the observed high uric acid output.

3. The total phosphorus excretion was high during the first three days and then showed a sharp diminution. There is marked retention of phosphorus by the new-born infant.

4. There is a moderate nitrogen retention during the first three days of life. Later, nitrogen is retained in large degree.

5. There is an inverse ratio between the leukocyte count and the elimination of phosphorus and uric acid during the first few days of life.

6 . In the light of our present knowledge, the parallelism between the excretion of uric acid and phosphorus during the first three days would seem to indicate a common origin from cell nuclei. The greater excretion of uric acid in the late ligation cases suggests that the formed elements of the blood in some way serve as its origin. ${ }^{65}$

We desire to thank Professor Gies for his kindness in placing the facilities of his laboratories at our disposal, and to acknowledge our great indebtedness to him and his associate, Dr. J. Rosenbloom, for much valuable assistance. We wish also to acknowledge our indebtedness to Dr. Rowland G. Freeman for permitting us to use the material from his service at the New York Nursery and Child's Hospital, and to thank the superintendent and nurses for their cooperation. We are also greatly indebted to Mr. F. W. Shaffer for much assistance in the supervision of the cases from the Nursery and Child's Hospital, and to Miss R. Feagin for her careful supervision of Case 9.

54 West One Hundred and Fourth Street-Troy, Texas.

65. In addition to the numbered references the following have been freely consulted:

Hall: The Purin Bodies, 1904.

Hill: Recent Contributions to Physiology and Biochemistry, 1906.

Wiener: Ergebnisse der Physiologie, 1902, i, 555; 1903, ii, 377.

McCrudden: The Chemistry, Physiology and Pathology of Uric Acid, 1905.

Barker: Truth and Poetry Concerning Uric Acid, 1905.

Mendel: Harvey Lecture, 1905-1906, Jour. Am. Med. Assn., 1906, xivi, 842 and 944.

Lusk: The Science of Nutrition, 1909. 
protocol I.-Case 1.-Immediate Ligation of Umbilical Cord, First Child

\begin{tabular}{|c|c|c|c|c|c|}
\hline 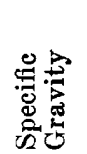 & 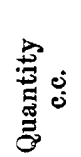 & 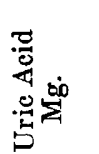 & 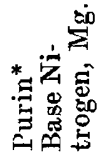 & 㤩 & $\begin{array}{l}\text { Leukocytes } \\
\text { per c.mm. } \\
\text { of Blood }\end{array}$ \\
\hline 1014 & 32 & 43. & 2.3 & 136. & 28,100 \\
\hline 1018 & 25 & 23.8 & 2.3 & 148.2 & 14,000 \\
\hline 1011 & 130 & 101.6 & 4.7 & 269.4 & 17,400 \\
\hline 1004 & 280 & 98.5 & 12.9 & 243.1 & 14,200 \\
\hline 1005 & 350 & 75.2 & 12.9 & 199.6 & 12.700 \\
\hline 1005 & 290 & 45.3 & 4.5 & 284.1 & 8,000 \\
\hline 1004 & 290 & 43.8 & 6.5 & 310. & 11,700 \\
\hline 1004 & 360 & 50.6 & 4.9 & 308.1 & 11,000 \\
\hline
\end{tabular}
method.

*Daily determination by Kenneway's modification of the Cammerer-Arnstein

PROTOCOL II.-Case 2.-Late Ligation of Umbilical Cord. Second Child

\begin{tabular}{|c|c|c|c|c|c|c|c|}
\hline \multirow[b]{2}{*}{ Day } & \multirow[b]{2}{*}{$\begin{array}{l}\text { Weight, } \\
\text { Gm. }\end{array}$} & \multicolumn{5}{|c|}{-Urine } & \multirow[b]{2}{*}{$\begin{array}{l}\text { Leukocytes } \\
\text { per c.mm. } \\
\text { of Blood }\end{array}$} \\
\hline & & 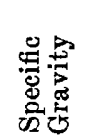 & 怘 & 苞 & 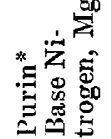 & 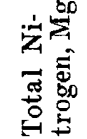 & \\
\hline 5 hours & $. .3,568$ & 1016 & 30 & 47.5 & 3.7 & 127.6 & 24,500 \\
\hline & . . 3,269 & 1010 & 32 & 76.5 & 2.7 & 142. & 14,300 \\
\hline & $.3,227$ & 1010 & part lost & & $\ldots$ & $\ldots$ & 7,300 \\
\hline & $. .3,269$ & 1007 & 310 & 77.5 & 7.1 & 220. & 7,600 \\
\hline & .. 3,227 & 1005 & 310 & 53.7 & 1.4 & 310.8 & 7,500 \\
\hline & $. .3,255$ & 1005 & part lost & & $\cdots$ & & 12,600 \\
\hline & $\ldots 3,295$ & 1005 & 268 & 50. & 4.3 & 196.4 & 13,200 \\
\hline & & & & & & & 11,400 \\
\hline
\end{tabular}
method.

*Daily determination by Kenneway's modification of the Cammerer-Arnstein

PRotocol III.-Case 3.-Late Ligation of Umbilical Cord. First Child

\begin{tabular}{|c|c|c|c|c|c|c|c|}
\hline \multirow[b]{2}{*}{ Day } & \multirow[b]{2}{*}{$\begin{array}{l}\text { Weight, } \\
\text { Gm. }\end{array}$} & & & & \multirow[b]{2}{*}{$\begin{array}{l}\text { Leukocytes } \\
\text { per c.mm } \\
\text { of Blood }\end{array}$} \\
\hline & & 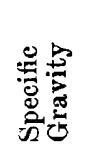 & 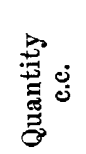 & 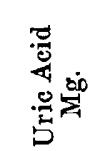 & 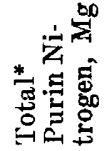 & 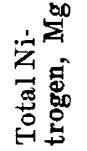 & \\
\hline 1. 24 hours & $\ldots 3,479$ & 1020 & 12 & 37.8 & $\ldots$ & 169.4 & 38,000 \\
\hline $2 . \ldots \ldots$ & $.3,367$ & 1012 & 110 & 142.5 & 73.8 & 342.1 & 15,800 \\
\hline 3. & $. .3,367$ & 1007 & 210 & 104.16 & 49.7 & 326.2 & 11,600 \\
\hline 4. & $.3,339$ & 1005 & 280 & 56.6 & 22.6 & 266.5 & 11,000 \\
\hline 5. & $\ldots 3,425$ & 1005 & 370 & 37. & 14.3 & 355.8 & 14,000 \\
\hline 6. & $\ldots 3,425$ & 1007 & 365 & 42.8 & 18.5 & 347.4 & 14,400 \\
\hline 7. & $\ldots 3,507$ & 1005 & 275 & 31. & 14.1 & 261.8 & 17,900 \\
\hline & $\ldots 3,624$ & 1004 & 390 & 29.9 & 12.2 & 371.2 & 13,700 \\
\hline
\end{tabular}

* Daily determination by the method of Krüger and Schmid. 


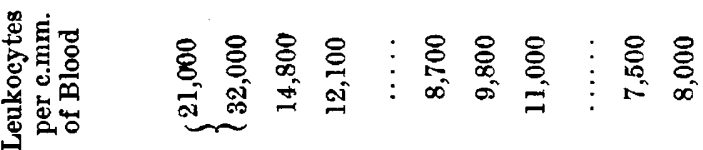

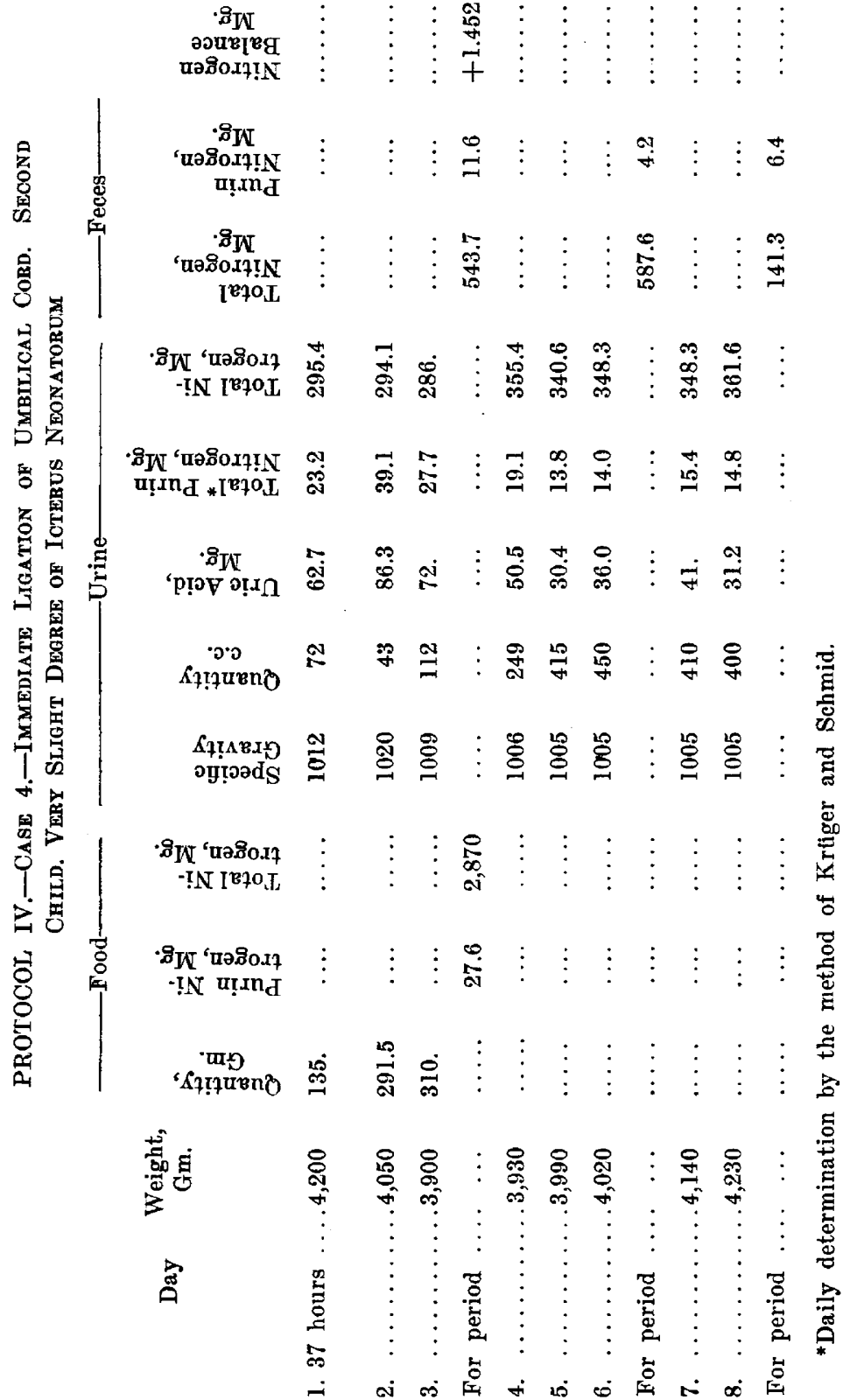




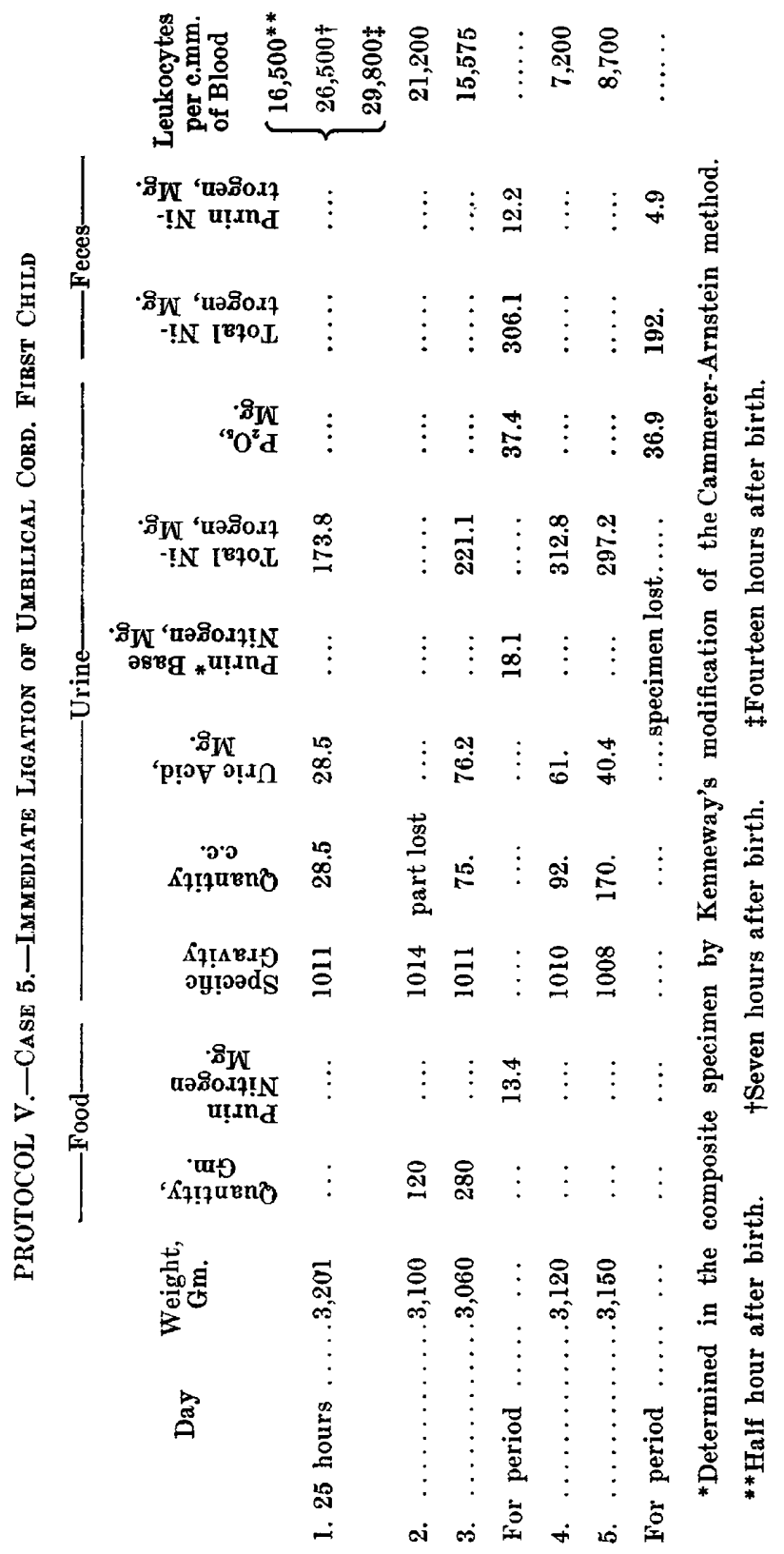




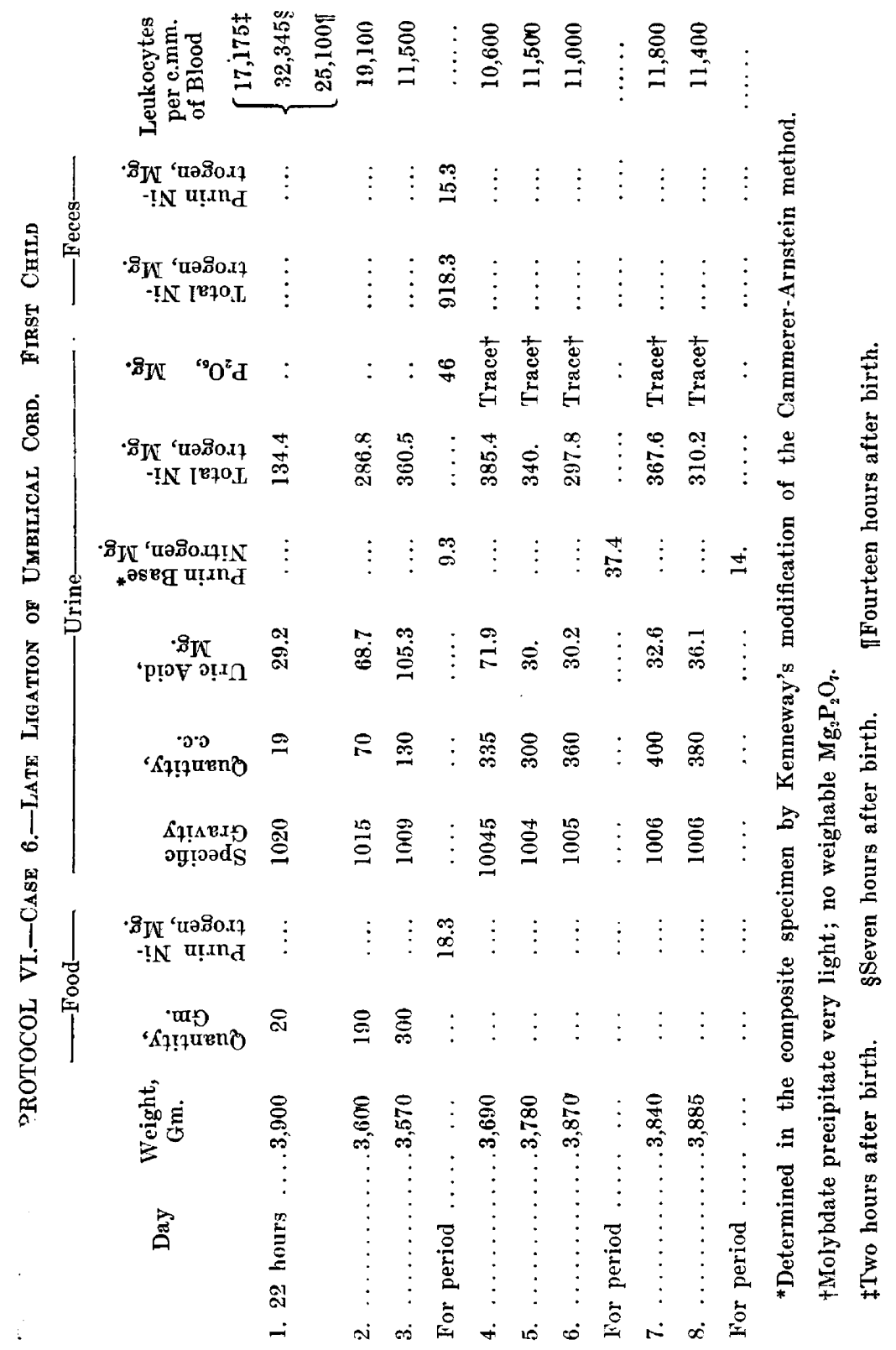




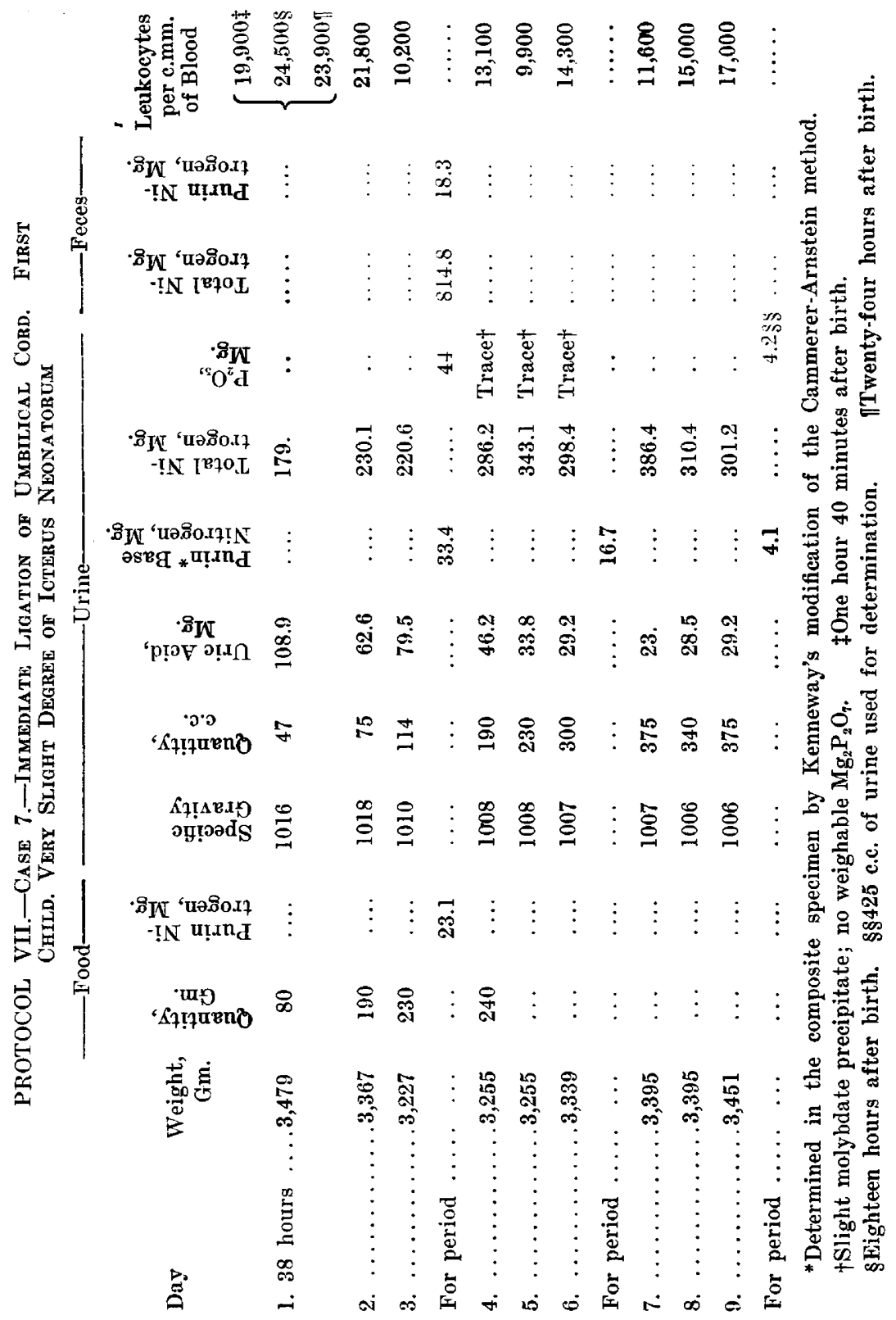


Protocol ViII.-Case 8.- Late Ligation of Umbilical Cord. First Child

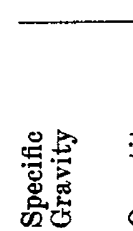

1.31 him 3.310

1012

1015

10075

3. ...... 2,998

....

For period. . .

4. ......2,970

1008

5. ..... 2,879

1007

6. $\ldots \ldots 2,942$

1007

For period $\ldots$

7. ..... 2,998

....

8. ...... 3,044

1007

1007

9. ..... 3,044

1007

For period $\ldots$
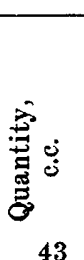

39

240

...

182

222

270

...

275

290

320 Urine

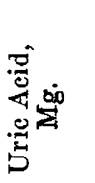

116.9

68.4

98.4

.....

36.2

40.6

35.9

.....

....

31.6

40.

29.4

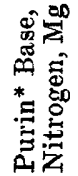

....

....

.

…

33.8

...

....

$\cdots$

14.8

… 374

374.

328.8

253.7

3.4

‡Slight molybdate precipitate; No weighable $\mathrm{Mg}_{2} \mathrm{P}_{2} \mathrm{O}_{7}$.

$\S I n$ cubic centimeters of $\mathrm{N} / 10 \mathrm{NaOH}$.

"Determined in the composite specimen by Kenneway's modification of the Cammerer-Arnstein method.

TThe urine used for the determination of the acidity was afterwards used in the phosphorus determination. Since free oxalic acid interferes with the precipitation of ammonium phosphomolybdate, blank determinations were made. Duplicate phosphorus determinations were made in a solution of sodium dihydrogen phosphate with the following results:

Magnesium PYrophosphate, Gm.

1. 25 c.e. of phosphate solution 0.0395 0.0398

2. 25 c.c. of phosphate solution with the addition of nitric and sulphuric acids $\ldots \ldots \ldots . \ldots 0396$

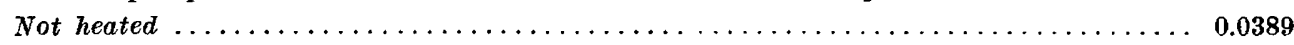

3. 25 c.c. of phosphate solution with the addition of nitric and sulphuric acids

and $10 \mathrm{gm}$. of potassium oxalate No molybdate Not heated. precipitate.

4. 25 c.c. of phosphate solution with the addition of nitric and sulphuric acids and 10

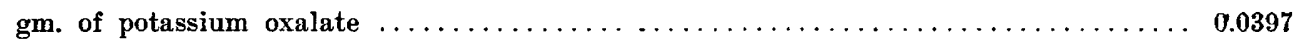

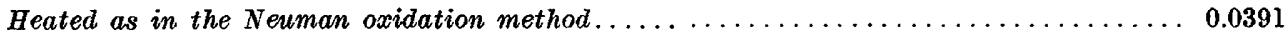

It is thus seen that when the Neuman method of oxidation is used, the presence of oxalic acid does not interfere with the determination. 


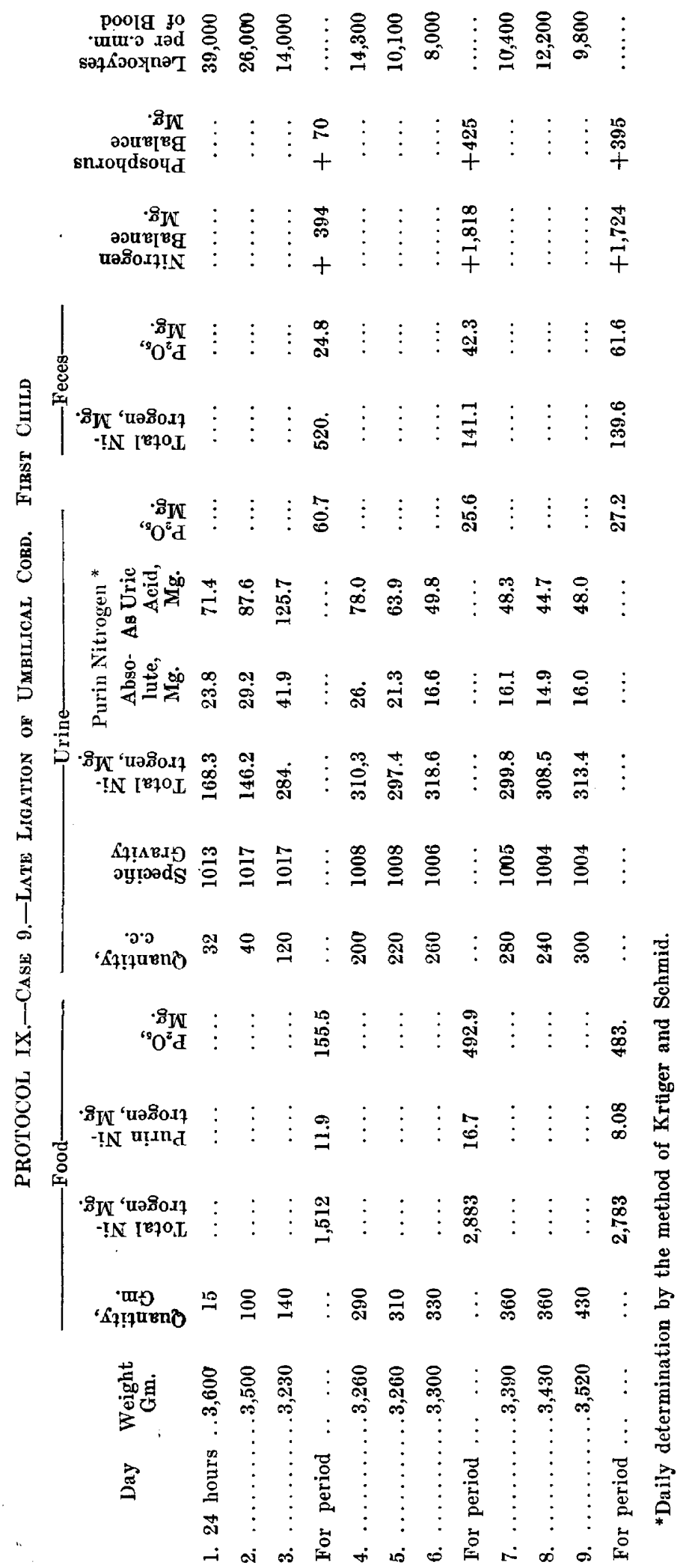

Downloaded From: http://archpedi.jamanetwork.com/ by a University of California - San Diego User on 06/11/2015 